\title{
Functional capacity and sociodemographic conditions of older people with leprosy sequelae in the Dr Geraldo da Rocha Hospital, Colônia Antônio Aleixo, Manaus, Amazonas, Brazil
}

\begin{abstract}
Goals: To evaluate the degree of functional capacity and sociodemographic conditions of older people with leprosy sequelae in the Dr Geraldo da Rocha Hospital, Manaus, Amazonas, Brazil.

Methods: a descriptive cross-sectional research study approach using an individual structured interview script (questionnaire), with both open and closed questions about Activities of Daily Living (ADLs), and Independent Activities of Daily Living (IADLs) being complemented with sociodemographic information.

Results: the subjects were 34 older people: $21(61.75 \%)$ older women and $13(38.25 \%)$ older men. Of these older women, $33.33 \%$ were illiterate; in older men, this percentage was $61.54 \%$. Questioned about the civil status, $23.81 \%$ of the older women and $23.08 \%$ of the older men affirmed to be married; $47.62 \%$ of the older women and $46.15 \%$ of the older men were widows. About the economic situation, 52.94\% survived with 01 minimum wage. In relation to health status, $57.14 \%$ of the older women considered having good health, despite the sequelae left by leprosy; in contrast, only $38.46 \%$ of the older men reported having this same health status. In relation to memory, $61.90 \%$ of the older people stated that they had a good memory. Among the older people who participated in the survey, $82.35 \%$ had modified independence in relation to all daily activities. The greatest difficulty faced by these older people was to use public transportation for which 92.24 of older women and $100.00 \%$ of older men reported some degree of difficulty.

Conclusion: This study provides important basic information on the situation of older people with leprosy sequelae or affected by leprosy in the Leprosy General Hospital Dr Geraldo da Rocha and it can serve as a basis for managers in the hospital, municipal and state government levels to make the necessary decisions that lead to an improvement in the quality of life of these older people affected by this disease, institutionalized or not, in the same or different health conditions.
\end{abstract}

Keywords: older people, leprosy sequelae, functional capacity
Volume 5 Issue I - 2020

\author{
Rocha-Cavalcanti Lais da,' Nadia Cristina \\ Coelho-Sobral, ${ }^{2}$ Ana Felisa Hurtado- \\ Guerrero, ${ }^{3}$ José Camilo Hurtado-Guerrero ${ }^{4}$ \\ 'Nursing Residency in Gerontology, Post-graduation in ICU- \\ SOBRATI, Nurse at SUSAM and EBSERH, Brazil \\ 2Master in Nursing- UFAM, Nursing Residence in Women's \\ Health-UEA, Postgraduate Diploma in Public Health; Nurse at \\ SUSAM and EBSERH-HUGV, Brazil \\ ${ }^{3} \mathrm{PhD}$ in Public Health, Escola de Saúde Pública, Fiocruz, Rio de \\ Janeiro, Former Professor and Researcher of Colective Health \\ Course, School of Health Sciences, Universidade do Estado do \\ Amazonas-UEA, Brazil \\ ${ }^{4}$ Post-Doc in Animal Behaviour, Canadá and PhD in Biologica \\ Sciences, Instituto Nacional de Pesquisa da Amazônia-INPA- \\ UFAM, Professor and Researcher of Instituto de Biodiversidade \\ e Florestas-IBEF, Universidade Federal do Oeste do Pará - \\ UFOPA, Brazil
}

Correspondence: José Camilo Hurtado-Guerrero, Universidade Federal do Oeste do Pará-UFOPA, Instituto de Biodiversidade e Florestas-IBEF, Rua Vera Paz, s/n, Salé, Santarém, PA, Brazil, CEP: 68040-470, Tel 55 (92) 98405-3863, Email jhocamhur@gmail.com

Received: December 18, 2019 | Published: January 22, 2020
Abbreviations: BADLs, basic activities of daily living; ADLs, activities of daily living; IADLs, instrumental activities of daily living; UEA, universidade do estado do amazonas; TCLE, termo de consentimento livre e esclarecido (free and informed consent form); CONEP, comitê nacional de ética em pesquisa (national commission for ethics in research); CEP, comitê de ética em pesquisa (research ethics committee); IBGE, instituto brasileiro de geografia e estatística; FAPEAM, fundação de amparo à pesquisa do estado do amazonas.

\section{Introduction}

The natural process of ageing bringing with it physiological stress and pathologies, often of a genetic nature, degenerative and chronic diseases. ${ }^{1}$ Since ageing is a dynamic and progressive process in which there are morphological, functional and biochemical alterations that go altering progressively the organism, making it more susceptible to aggressions. ${ }^{2}$ It is noticed that in the changes related to age there are the presence of risk factors and the occurrence of chronic degenerative diseases, which determine for older people a certain degree of dependence, directly related to the loss of autonomy and difficulty to perform the Basic Activities of Daily Living (BADLs), interfering in their quality of life. ${ }^{3,4}$

One of the pathologies that leave sequelae is leprosy and it can be observed mainly in older people due to the fact that the disease has a slow development. As we know, leprosy is an infectious, degenerative and transmissible disease caused by bacillus Mycobacterium leprae $e^{5,6}$ (also known as Hansen's bacillus). Its nervous manifestations are always present because the peripheral nervous system is the place where the M. Leprae develops, thus causing sensitivity disorders in the affected nerve region and in skin lesions. The most affected nerves are the radial nerve (which when affected prevents the extension of the hand, producing the so-called "fallen hand"), the cubital (ulnar) nerve, the median nerve on the wrist, external sciatica popliteal nerve (when affected preclude the foot from remaining in the normal position and makes the gait), the posterior tibial and the upper branch of the vagus nerve, ${ }^{7}$ leading people who suffer from this disease, gradually to the loss of their functional capacity. ${ }^{8,9}$

The functional capacity, especially in the motor dimension, is one of the most important markers of successful ageing and quality of life 
of the older people. ${ }^{10}$ This loss of functional capacity is associated with the prediction of fragility, dependence, institutionalization and increased risk of falls, death and mobility problems, bringing complications over time and generating long-term care and high cost. It has been found that it is much easier to avoid deaths than to avoid the development of disabilities associated with ageing. Each year, about $10.00 \%$ of the older adult population life is deeply affected by impeding them from performing activities such as bathing, dressing, eating and personal hygiene. ${ }^{11}$

The functional capacity is the independence to perform the activities of daily living. ${ }^{12}$ However, the functional capacity goes beyond the performance of daily activities. This is the ability to maintain the physical and mental skills necessary for an independent life, valuing autonomy and self-determination..$^{13}$ Therefore, from these concepts, it can be understood that functional capacity is a set of physical, intellectual and emotional needs that each individual has and must have. The factors most strongly associated with functional capabilities are related to the presence of some diseases, disabilities or medical problems. However, it is observed through some studies that this capacity also is influenced by factors such as demographic, socioeconomic, cultural and psychosocial factors and it is of great importance to evaluate them in order to know their influence on the functional capacity of the older people. ${ }^{14}$

Some researcher as Katz et al., ${ }^{14}$ Lawton-Brody ${ }^{15}$ and Paula ${ }^{16}$ proposed two scales of functional assessment that classified daily activities in consensus to their level of complexity. The first scale, the Activities of Daily Living (ADLs), is represented by the basic activities that are required in the daily lives of older people. While the second scale, which concerns about Instrumental Activities of Daily Living (IADLs), is represented by more complex tasks that require an adaptation of the individual in the environment. The ADLs and IADLs are activities that, for older people, have a high degree of complexity, especially for those older people with leprosy sequelae.

Functional capacity is considered a new health paradigm, ${ }^{17}$ it is being of crucial value for prevention and health promotion of older people. It is thought that carrying out researches in this sense, we will be able, in the future to: diagnose, treat, rehabilitate and avoid in the older people these kinds of complications. In this respect, this study aimed to evaluate the functional capacity and sociodemographic conditions of older people with leprosy sequelae in the Dr Geraldo da Rocha Hospital, Colônia Antônio Aleixo, Manaus, Amazonas, Brazil.

\section{Methods}

\section{Type of Study}

This research was a descriptive cross-sectional research study approach.

\section{Place of study}

The research was developed in the leprosary sector of the Dr Geraldo da Rocha Hospital located at Tancredo Neves Street - s/n, Colônia Antônio Aleixo, Manaus, Amazonas.

\section{Population}

The research consisted of a census of all the older with leprosy sequelae residents in the hospital, who, at the moment of this research, currently represented a population of 34 . Of these, 13 were older men and 21 were older women.

\section{Inclusion criteria}

The inclusion criteria considered were: 1) age $\geq 60$ years, 2) currently residing in the Dr Geraldo da Rocha Hospital, 3) agreeing to participate in the research, 4) signing the informed consent form (ICF) and 5) to have cognitive conditions to answer the questions or a caregiver to do so.

\section{Data collection instrument}

As an instrument for data collection, we used an individual structured interview script (questionnaire), with both open and closed questions. The questionnaire used was adapted from Fonseca ${ }^{18}$ and complemented with others. ${ }^{19,20}$ It contained questions related to functional capacity and sociodemographic profile of the older people with leprosy sequelae.

\section{Ethical aspects}

This research involving human beings was approved by the Secretaria Municipal de Saúde de Manaus - SEMSA (Manaus Municipal Health Secretariat) and the Comitê de Ética em Pesquisa - CEP (Research Ethics Committee) of Escola Superior de Ciências da Saúde (College of Health Sciences) of the Universidade do Estado do Amazonas - UEA (The University of the State of Amazonas) (process number - 052/09, 11/05/09) observing the resolution 196/96, of the Comitê Nacional de Ética em Pesquisa (CONEP) (National Commission for Ethics in Research), regarding the rights of individuals subject to research, related to ethical principles such as study benefits, privacy, non-maleficence, justice, autonomy and veracity.

\section{Data collection}

After approval by the Research Ethics Committee, the study subjects were informed about the objective, necessity and importance of the project. As the subjects agreed, they signed the ICF, consenting with the participation of the research. Interviews and data collection were conducted in the morning and afternoon hours in leprosy sector of the Geraldo da Rocha Hospital, Colônia Antônio Aleixo, Manaus, in 2010, with the collaboration of nurses and other health agents and caregivers who were willing to collaborate, after a brief presentation of the researchers and the research project to the older people with leprosy sequelae. In cases where the older people for some reason could not respond to the interview, an indirect interview was conducted with the caregiver of them. It is worth mentioning that all interviewees or caregivers interviewed also had to sign the ICF.

\section{Data analysis}

The collected data were organized in a database Microsoft Office Excel v. 2010 for subsequent statistical analysis. Data pertinent to the socio-demographic, economic and epidemiological profile and on the capacity of the older people to perform ADLs and Instrumental IADLs were analyzed using descriptive statistics. ${ }^{21-25}$ Data were analyzed with the following software: Minitab v.14, SPSS v.20 and Epi Info v.6 and 7.1.

\section{Results and discussion}

The group of older people studied was thirty-four (34). The older women had a representation of $61.75 \%$ and the older men of $38.25 \%$. This result confirms the Brazilian reality with respect to a higher index of older women in relation to older men in the third age. ${ }^{26-28}$ Of these older people, illiterate older women were $33.33 \%$; already for older men, this percentage was $61.54 \%$ (Table 1). These percentages 
are compatibles with $11.00 \%$ completed primary school obtained by Alves et al. ${ }^{29}$ in Juiz de Fora, Minas Gerais. While Hurtado-Guerrero et al. ${ }^{28}$ in Manacapuru, Amazonas, reported that $35.90 \%$ had an uncompleted primary school.

Table I Education, conforming to sex, for older people with leprosy sequelae in the Dr Geraldo da Rocha Hospital, Colônia Antônio Aleixo, Manaus, Amazonas, Brazil.

\begin{tabular}{lllllll}
\hline \multirow{2}{*}{$\begin{array}{l}\text { Variable } \\
\text { Educational status }\end{array}$} & \multicolumn{2}{c}{ Older women } & \multicolumn{2}{c}{ Older men } & \multicolumn{2}{c}{ Total } \\
\cline { 2 - 7 } & $\mathbf{n}$ & $\%$ & $\mathbf{n}$ & $\%$ & $\mathbf{n}$ & $\%$ \\
\hline Literate & 14 & 66.67 & 5 & 38.46 & 19 & $\mathbf{5 5 . 8 8}$ \\
IIliterate & 7 & 33.33 & 8 & 61.54 & $\mathbf{1 5}$ & $\mathbf{4 4 . 1 2}$ \\
Total & $\mathbf{2 1}$ & 100.00 & $\mathbf{1 3}$ & 100.00 & $\mathbf{3 4}$ & $\mathbf{1 0 0 . 0 0}$ \\
\hline
\end{tabular}

Source: authors; $\mathbf{n}$, sample size; \%, percentage

Table 2 Marital status, pursuant to sex, for older people with leprosy sequelae in the Dr Geraldo da Rocha Hospital, Colônia Antônio Aleixo, Manaus, Amazonas, Brazil.

\begin{tabular}{lllllll}
\hline Variable & \multicolumn{2}{c}{ Older women } & \multicolumn{2}{c}{ Older men } & \multicolumn{2}{c}{ Total } \\
\cline { 2 - 7 } Marital status & $\mathbf{n}$ & $\%$ & $\mathbf{n}$ & $\%$ & $\mathbf{n}$ & $\%$ \\
\hline Widower & 10 & 47.62 & 6 & 46.15 & 16 & $\mathbf{4 7 . 0 6}$ \\
Divorced & 4 & 19.05 & 4 & 30.77 & $\mathbf{8}$ & $\mathbf{2 3 . 5 3}$ \\
Married & 5 & 23.81 & 3 & 23.08 & $\mathbf{8}$ & $\mathbf{2 3 . 5 3}$ \\
Single & 2 & 9.52 & 0 & 0.00 & $\mathbf{2}$ & $\mathbf{5 . 8 8}$ \\
Total & 21 & 100.00 & 13 & 100.00 & $\mathbf{3 4}$ & $\mathbf{1 0 0 . 0 0}$ \\
\hline
\end{tabular}

Source: authors; $\mathbf{n}$, sample size; \%, percentage

Questioned about marital status, $23.81 \%$ of older women and $23.08 \%$ of older men said they were married; $47.62 \%$ of older women and $46.15 \%$ of older men were widows (Table 2 ). As confirmed by Ricci et al. ${ }^{30}$ and Camarano et al., ${ }^{31}$ there is a high prevalence of widowed, divorced or single older people, data also attested by the present study. The fact that older people do not have a spouse can directly influence their self-care, since the lack and especially the loss of a company can lead to depression and thus them may become displeased with their physical and physiological needs, thus becoming more vulnerable to various diseases.

In the identification of the professional activities exercised by the older people previously, since $100.00 \%$ of older people were retired, the following ones were found: agriculture was the predominant profession in this group (41.06\%) and others such as domestic works, carpentry, health, car mechanics and general services, represented (58.94\%), it was similar to the outcome found in other studies. ${ }^{32,33}$ The main cause why older people getting to be all retired was mutilations, especially in limbs, caused by Hansen's bacillus, thus making retirement wages the only source of income for all them, coinciding with the research of Nogueira et al. ${ }^{34}$ when it analyzed the functional capacity of older with leprosy in Fortaleza. Agriculture appeared as a predominant activity exercised by the older people before the sequels left by leprosy, due to the fact that they came from various interior settlements in which one of the most profitable and viable activities is the cultivation of land.

Through the study, it was also possible to make an analysis of the economic situation of these older people, being observed that $52.94 \%$ of them received only 01 minimum wage and only $11.76 \%$ received 04 minimum wages monthly. As stated by the above percentages, most of the older people surveyed had a monthly income of only one minimum wage. $\operatorname{Ramos}^{26}$ and Sakamoto et al. ${ }^{33}$ affirmed that the financial situation of the older people is directly related to their physical and mental health and is associated with the low functional capacity present mainly in those older people with low income. In conformity with data from IBGE, ${ }^{27,35}$ the economic conditions of these older people are compatible with those of the whole country, considering that about $50.00 \%$ of them in Brazil have a monthly income lower than or equal to a minimum wage.

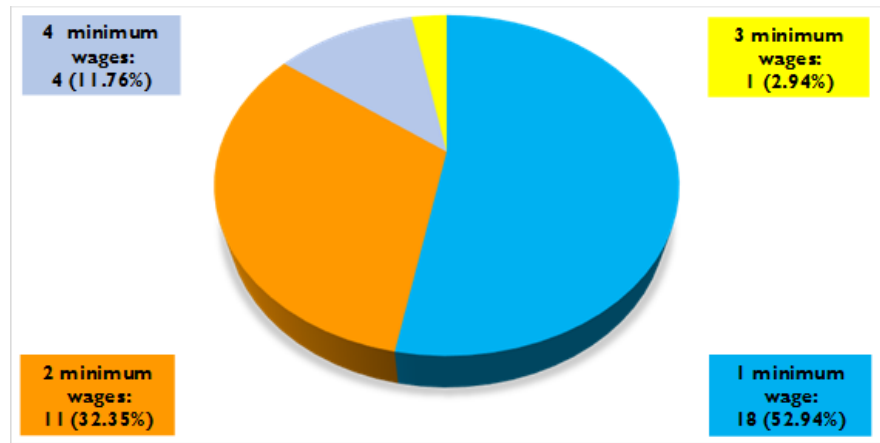

Figure I Income distribution of older people with leprosy sequelae in the Dr Geraldo da Rocha Hospital, Colônia Antônio Aleixo, Manaus, Amazonas, Brazil. Source: authors.

This study also sought to identify the social participation of these older people with leprosy sequelae, to know their level of social inclusion, since they are constantly targeting of bullying prejudiced attitudes due to their mutilations resulting from the advancement of the disease. It was observed that only $35.29 \%$ of these individuals practice some social activity, while $64.71 \%$ never participated in such activities. However, all of them reported participating only in 
religious groups. Several studies have claimed that religion can reduce the fear of death experienced by some older people. ${ }^{36-40}$ Through their studies ${ }^{36,39}$ with older people who had depression, these researchers demonstrated that mental health also improves with religiosity, and these people recovered $70.00 \%$ faster than the others. ${ }^{36}$

With regard to the care of this older people in cases of illness or help, in general, this study found that the caregivers are, in the vast majority of cases, belonging to the family itself, especially represented by sons $(44.12 \%)$ and grandchildren $(23.53 \%)$. Others such as wives, friends, health workers and volunteers (32.35\%). The others, concerned people who worked for them doing household chores, since they have no relatives or friends who could help them. As stated by diverse studies, ${ }^{41-43}$ the household arrangement showed that Brazilians older people still live, mostly, sharing the household with children and sometimes with children and grandchildren. This type of household can be called multigenerational and accommodates $50.00 \%$ of older people in this country. For this reason, the data confirmed more intense family support to them. In contrast, this situation is not experienced in the countries of Europe, since the older people population of these countries lives mostly alone.
The older people also were asked to inform how they classified their state of health and memory. Concerning health status, $57.14 \%$ of the older women considered having good health, despite the sequelae left by leprosy. In contrast, only $38.46 \%$ of older men reported having this same health status. In relation to memory, $61.90 \%$ of older women and older men stated that they had a good memory (Table 3). As explained before, most of them considered themselves to be in good health. And most of them in this study, when analyzing the variables of functional capacity, have some degree of dependence. ${ }^{4,44}$ This research confirms a previous study which was found to be at greater risk, for the development of functional disabilities, older people who had a more pessimistic assessment in relation to their health status. ${ }^{29,45}$ The ageing process is a period of life in which there are the appearance and prevalence of chronic diseases, physical disability, cognitive loss ${ }^{46,47}$ and social isolation. The results of this research show that $85.29 \%$ of them self-evaluate their health as good or regular, being compatible with another studies ${ }^{2,57}$, in which $6.00 \%$ of the older people declared to have good health and only $6.00 \%$ considered to have a very poor state of it.

Table 3 State of health and memory, related to sex, of the older people with leprosy sequelae in the Dr Geraldo da Rocha Hospital, Colônia Antônio Aleixo, Manaus, Amazonas, Brazil

\begin{tabular}{|c|c|c|c|c|c|c|c|c|c|c|c|c|}
\hline \multirow[b]{3}{*}{ Health status and memory } & \multicolumn{5}{|c|}{ Health } & \multicolumn{7}{|c|}{ Memory } \\
\hline & \multicolumn{2}{|c|}{ Older women } & \multicolumn{2}{|c|}{ Older men } & \multicolumn{2}{|c|}{ Total } & \multicolumn{2}{|c|}{ Older women } & \multicolumn{2}{|c|}{ Older men } & \multicolumn{2}{|c|}{ Total } \\
\hline & $\mathrm{n}$ & $\%$ & $n$ & $\%$ & $n$ & $\%$ & $n$ & $\%$ & $n$ & $\%$ & $n$ & $\%$ \\
\hline Great & 0 & 0.00 & 0 & 0.00 & 0 & 0.00 & I & 4.76 & 2 & 4.76 & 3 & 8.82 \\
\hline Good & 12 & 57.14 & 5 & 38.46 & 17 & 50.00 & 13 & 61.90 & 3 & 61.90 & 16 & 47.06 \\
\hline Regular & 7 & 33.33 & 5 & 38.46 & 12 & 35.29 & 6 & 28.57 & 6 & 28.57 & 12 & 35.29 \\
\hline Bad & 2 & 9.52 & 3 & 23.08 & 5 & $|4.7|$ & I & 4.76 & 2 & 4.76 & 3 & 8.82 \\
\hline Total & 21 & 100.00 & 13 & 100.00 & 34 & 100.00 & 21 & 100.00 & 13 & 100.00 & 34 & 100.00 \\
\hline
\end{tabular}

Source: authors; $\mathbf{n}$, sample size; \%, percentage

When asked about the pain, $29(89.29 \%)$ of the older people reported feeling pain constantly in at least one part of the body, while $5(14.71 \%)$ were living without pain. As it is shown below (Figure 2), of 29 older people with pain, their most affected body segments were: eyes (17.24\%), spine (17.24\%), legs (13.79\%), bones $(13.79 \%)$ and hands $(10.34 \%)$. Other health concerns represented $(27.59 \%)$. In this group studied there was a particularity in relation to eyes pain since they had the loss of visual capacity more pronounced than in the normal older people because the bacillus that causes leprosy affects the anterior segment of the eye and it is the iris most affected. ${ }^{48,49}$ Pain in the limbs and joints are also common in the older people with leprosy sequelae because $M$. leprae also affects the peripheral nerves causing pain and mutilation.

The older people who said to have the independence to take their medications at the right time represented $88.24 \%$ of those surveyed. It was observed that $11.76 \%$ of the older people needed help to remember that they should take their medications, to take them at the right time or to pick them up. This result is similar to those identified by other studies, ${ }^{50-52}$ who in their researches showed that near $12.40 \%$ of all older people had the same difficulties to take the medications like those of the Dr Geraldo da Rocha Hospital.

This study also aimed to identify the older people who make use of self-medication, that is, respecting the purchase of medicine without a prescription, excluding the cases in which they return to purchase a medicine previously prescribed. It was found that among older women this practice is present in $38.10 \%$ of them. This percentage rises to $46.15 \%$ for older men, with an average of $41.18 \%$ for both older people making use of self-medication. Self-medication is a very common practice adopted by the vast majority of the population. The main causes for its existence are: the great impossibility of a good part of the people to have access to the medical or dentistry attendance either for financial questions or for a proper habit to try to solve the problems of ordinary health, besides the high frequency of advertisements through the electronic media that is many times a contributing factor for the self-medication of lay people in the subject. ${ }^{53}$ Self-medication may result in a drug interaction that is when 
drugs that are administered concomitantly interact with each other. They can interact in three basic ways: one can potentiate the action of another, can also occur the loss of effects by opposite actions or even the action of a drug altering the absorption, transformation in the organism or the excretion of another drug harming thus the welfare and health mainly of the older people..$^{54}$

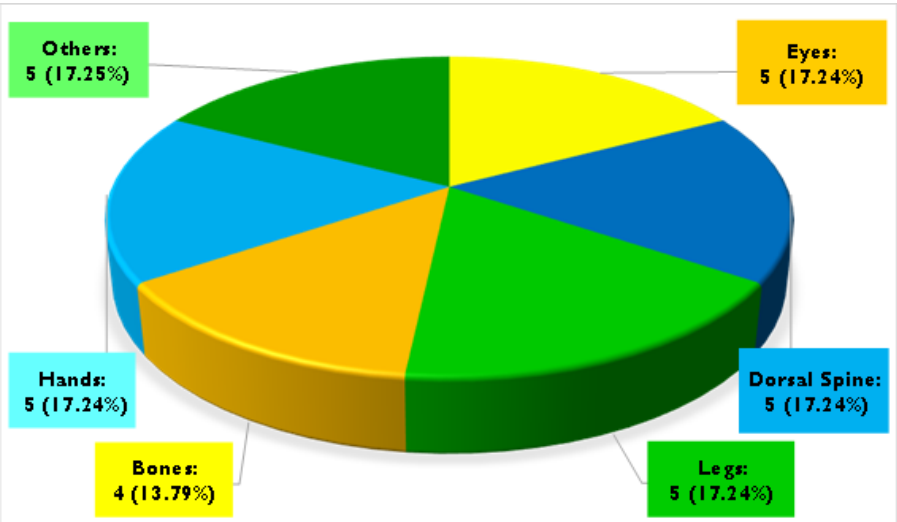

Figure 2 Body location of pain experienced by the older people with leprosy sequelae in the Dr Geraldo da Rocha Hospital, Colônia Antônio Aleixo, Manaus, Amazonas, Brazil. Source: authors.

Through the instrument of the ADLs and IADLs, it was verified that, in general, only $14.28 \%$ older women and $23.08 \%$ of older men needed help to perform these activities (Table 4).

Table 4 Evaluation scores of functional capacity of the Activities of Daily Living (ADLs) and Independent Activities of Daily Living (IADLs) of the older people with leprosy sequelae in the Dr Geraldo da Rocha Hospital, Colônia Antônio Aleixo, Manaus, Amazonas, Brazil

\begin{tabular}{|c|c|c|c|c|c|c|}
\hline \multirow{2}{*}{$\begin{array}{c}\text { Variable } \\
\text { Scores (points) }\end{array}$} & \multicolumn{2}{|c|}{ Older women } & \multicolumn{2}{|c|}{ Older men } & \multicolumn{2}{|c|}{ Total } \\
\hline & $\mathbf{n}$ & $\%$ & $\mathbf{n}$ & $\%$ & $\mathbf{n}$ & $\%$ \\
\hline $0-83$ & 0 & 0.00 & 0 & 0.00 & 0 & 0.00 \\
\hline $144-175$ & 18 & 85.72 & 10 & 76.92 & 28 & 82.35 \\
\hline Total & 21 & 100.00 & 13 & 100.00 & 34 & 100.00 \\
\hline
\end{tabular}

Source: authors; $\mathbf{n}$, sample size; \%, percentage

0-83, independence, 84- I 43, modified dependence (requires 25\% help); I 44 I75, modified/full independence

The ADLs and IADLs showed to be more complex for the older men with leprosy sequelae than for older women with the same conditions, being this result compatible with the study conducted by Lima. ${ }^{55}$ The general autonomy index of leprosy sequelae was similar to that of the older people who participated in the study by Alves ${ }^{29}$ in which only $5.9 \%$ of them presented a high dependence. Asked about the level of autonomy to perform ADLs associated with self-care, it was found that $91.18 \%$ of the older people do not report any difficulty to feed themselves, but $8.82 \%$ do it only with the help of another person at some point, such as when cutting food. With regard to food preparation, it was observed that $17.65 \%$ of the older people performed this activity with a small degree of difficulty due to problems in handling the utensils. This study found that $100.00 \%$ of the older people were totally independent to take a bath and no difficulty to perform this activity was reported. Already for dressing, a slight difficulty was reported by only $8.82 \%$ of them with no difference between sexes (Table 5). As in other studies conducted with older people, there was not much difficulty in bathing taking medication, dressing and eating. ${ }^{8,9}$

A slight difficulty was observed in the preparation of food, which was also identified in the study by Nogueira, ${ }^{9}$ whose percentage of older people needing assistance was $17.15 \%$, thus being very similar to this research. This study is also compatible with the study conducted by Navarro ${ }^{56}$ in which all the older people had a score compatible with independence in the scale of ADLs.

Another activity analyzed was the ability of the older people to cut their own nails. A greater difficulty was observed among older women $(14.29 \%)$ who presented to cut their nails (Table 6). This difficulty, reported by them was due to the fact that they have the impairment of the peripheral nerves, thus becoming without strength and/or dexterity to perform it. Another fact cited for this level of difficulty was the absence of some essential fingers for the exercise of this activity.

The ability to control the sphincters showed no difference between the sexes. It was observed that among both older people, $67.65 \%$ had their urinary continence preserved. Considering the control of the faecal sphincter, $64.61 \%$ of them had total control (Figure 3). Among the older people studied, $32.35 \%$ reported some degree of difficulty in controlling the urinary sphincter. This result was consistent with the study by Nakatani, ${ }^{50}$ in which $28.60 \%$ of the older people reported difficulty in controlling the urinary sphincter. Already for faecal sphincter, $35.29 \%$ showed difficult to control it, results very different to $6.60 \%$ obtained by the former author concluding that the older people have some degree of difficulty in controlling them. When the older people have urinary or faecal incontinence, many times it can go through embarrassing situations, leading them to restrict themselves in their home environment. This condition contributes to diseases such as loneliness, depression and cognitive impairment. It is recommended to the health team to identify and assess the reason for incontinence and create conducts that lead to the recovery of sphincter control..$^{50}$

Asked about the ability of the older people to move, it was found that only $29.41 \%$ can walk indoors without help. The percentage of them who considered themselves independent to climb stairs was $32.35 \%$, with no difference between the sexes (Figure 4). The difficulty of locomotion, such as walking indoors and climbing stairs, presented by the vast majority of the older people in this study, has also been mentioned in other studies ${ }^{9,44,45}$ but, in particular, in older people with leprosy sequelae left by leprosy, these rates tend to be higher once the Hansen's bacillus reaches the peripheral nerves, deteriorating the sensitivity and functionality of the upper and lower limbs. . $^{7,83}$

It was found a great difficulty among older people with leprosy sequelae in using public transportation. There was a prevalence of almost total dependence for this activity among older men reaching the index of $76.92 \%$, while in older women this was $28.57 \%$ (Figure 5). 
Table 5 Comparison of the degree of dependence and independence for the performance of Activities of Daily Living (ADLs) among the older people with leprosy sequelae in the Dr Geraldo da Rocha Hospital, Colônia Antônio Aleixo, Manaus, Amazonas, Brazil

\begin{tabular}{|c|c|c|c|c|c|c|c|c|c|c|c|c|c|c|c|c|}
\hline \multirow{3}{*}{$\begin{array}{l}\text { Variable } \\
\text { ADLs/self-care }\end{array}$} & \multicolumn{15}{|c|}{ Degree of dependence } & \multirow[b]{2}{*}{ Total } \\
\hline & \multicolumn{2}{|l|}{ I } & \multicolumn{2}{|l|}{2} & \multicolumn{2}{|l|}{3} & \multicolumn{2}{|l|}{4} & \multicolumn{2}{|l|}{5} & \multicolumn{2}{|l|}{6} & \multicolumn{3}{|l|}{7} & \\
\hline & $\mathrm{n}$ & $\%$ & $\mathrm{n}$ & $\%$ & $\mathrm{n}$ & $\%$ & $\mathrm{n}$ & $\%$ & $\mathrm{n}$ & $\%$ & $\mathrm{n}$ & $\%$ & $\mathrm{n}$ & $\%$ & $\mathbf{n}$ & $\%$ \\
\hline Feeding & 0 & 0.00 & 0 & 0.00 & 0 & 0.00 & 0 & 0.00 & I & 2.94 & 2 & 5.88 & 31 & 91.18 & 34 & 100.00 \\
\hline Bathe & 0 & 0.00 & 0 & 0.00 & 0 & 0.00 & 0 & 0.00 & 0 & 0.00 & 0 & 0.00 & 34 & 100.00 & 34 & 100.00 \\
\hline Food preparation & I & 2.94 & 0 & 0.00 & 0 & 0.00 & 0 & 0.00 & 0 & 0.00 & 5 & 17.65 & 27 & 79.41 & 34 & 100.00 \\
\hline Taking medication & 0 & 0.00 & 0 & 0.00 & 2 & 5.88 & 1 & 2.94 & 0 & 0.00 & I & 2.94 & 30 & 88.24 & 34 & 100.00 \\
\hline Dress & 0 & 0.00 & 0 & 0.00 & 0 & 0.00 & 0 & 0.00 & 0 & 0.00 & 3 & 8.82 & 31 & 91.18 & 34 & 100.00 \\
\hline
\end{tabular}

Source: authors; $\mathbf{n}$, sample size; \%, percentage

DI, total dependence; D2, need for75\% help; D3, need for 50\% help; D4, need for 25\% help; D5, need for supervision; D6, need for minimum help; D7, independence

Table 6 Degree of dependence for nail clipping among the older people with leprosy sequelae in the Dr Geraldo da Rocha Hospital, Colônia Antônio Aleixo, Manaus, Amazonas, Brazil

\begin{tabular}{lllllll}
\hline Variable & \multicolumn{2}{c}{ Older women } & \multicolumn{2}{c}{ Older men } & \multicolumn{2}{l}{ Total } \\
\cline { 2 - 7 } $\begin{array}{c}\text { Degree of dependence } \\
\text { to nail clipping }\end{array}$ & $\mathbf{n}$ & $\%$ & $\mathbf{n}$ & $\%$ & $\mathbf{n}$ & $\%$ \\
\hline D1 & 3 & 14.29 & 0 & 0.00 & $\mathbf{3}$ & $\mathbf{8 . 8 2}$ \\
D2 & $\mathrm{I}$ & 4.76 & 0 & 0.00 & $\mathbf{I}$ & $\mathbf{2 . 9 4}$ \\
D3 & 0 & 0.00 & 0 & 0.00 & $\mathbf{0}$ & $\mathbf{0 . 0 0}$ \\
D4 & 0 & 0.00 & 0 & 0.00 & $\mathbf{0}$ & $\mathbf{0 . 0 0}$ \\
D5 & 1 & 4.76 & 2 & 15.38 & $\mathbf{3}$ & $\mathbf{8 . 8 2}$ \\
D6 & 8 & 38.10 & 4 & 30.77 & $\mathbf{I 2}$ & $\mathbf{3 5 . 2 9}$ \\
D7 & 8 & 38.10 & 7 & 53.85 & $\mathbf{1 5}$ & $\mathbf{4 4 . 1 2}$ \\
Total & 21 & 100.0 & 13 & 100.0 & $\mathbf{3 4}$ & $\mathbf{1 0 0 . 0}$ \\
\hline
\end{tabular}

Source: authors; $\mathrm{n}$, sample size; \%, percentage

DI, total dependence; D2, need for75\% help; D3, need for 50\% help; D4, need for 25\% help; D5, need for supervision; D6, need for minimum help; D7, independence

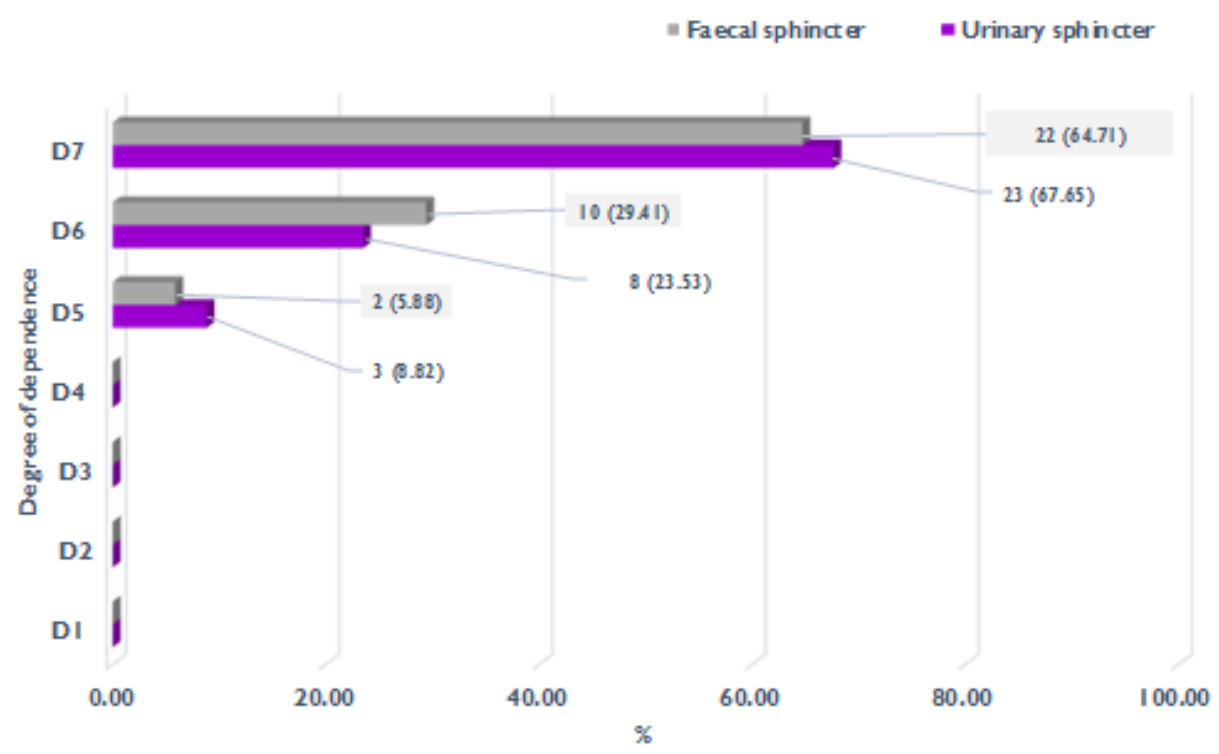

Figure 3 Degree of control of urinary and faecal sphincters among the older people with leprosy sequelae in the Dr Geraldo da Rocha Hospital, Colônia Antônio Aleixo, Manaus, Amazonas, Brazil. Source: authors.

DI, total dependence; D2, need for75\% help; D3, need for 50\% help; D4, need for 25\% help; D5, need for supervision; D6, need for minimum help; D7, independence.

Citation: Rocha-Cavalcanti LD, Coelho-Sobral NC, Hurtado-Guerrero AF, et al. Functional capacity and sociodemographic conditions of older people with leprosy sequelae in the Dr Geraldo da Rocha Hospital, Colônia Antônio Aleixo, Manaus,Amazonas, Brazil. MOJ Gerontol Ger. 2020;5(I): I0-2I. DOI: 10.15406/mojgg.2020.05.00223 


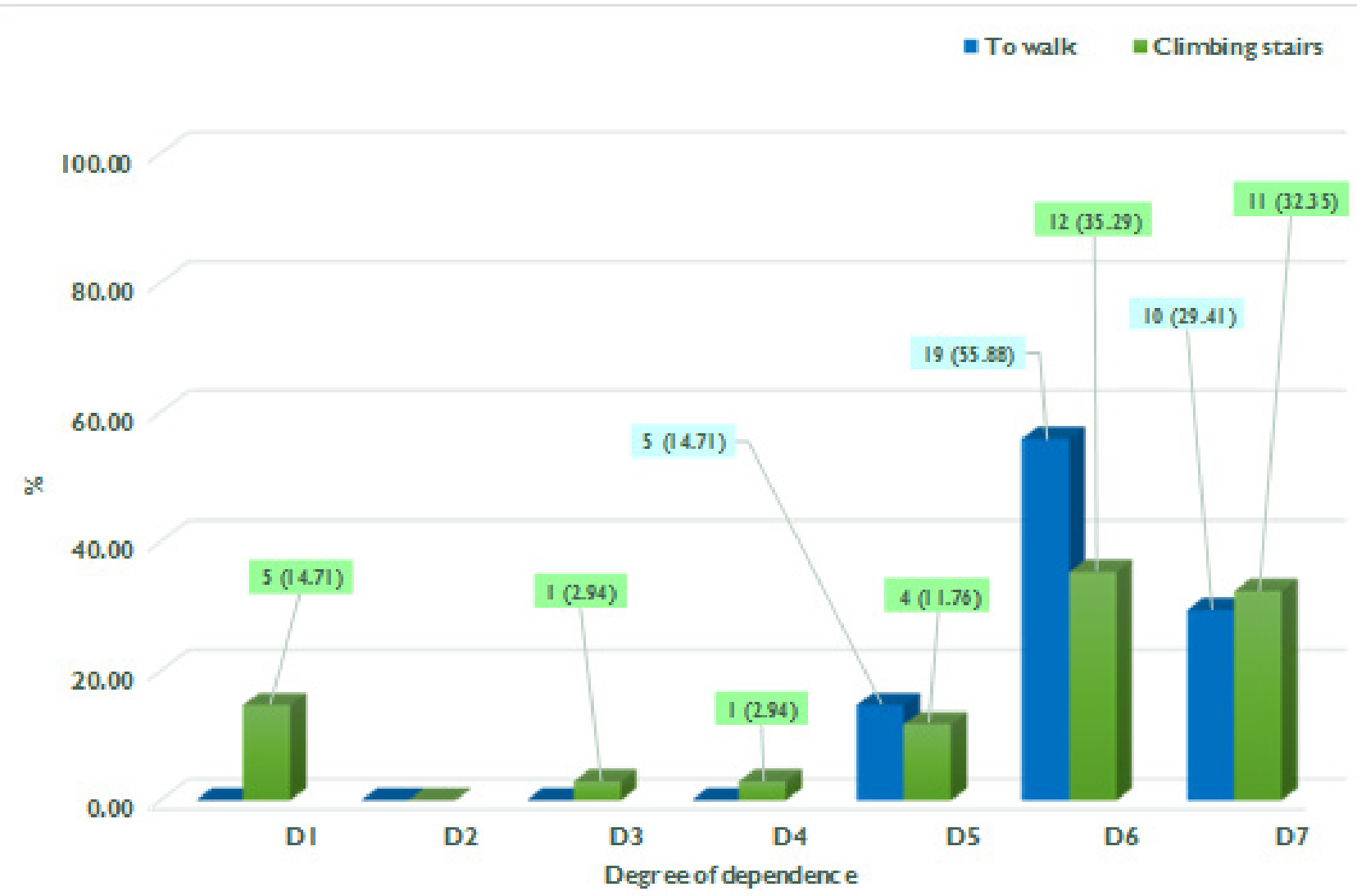

Figure 4 Degree of dependence to climb stairs and walk indoors among the older people with leprosy sequelae in the Dr Geraldo da Rocha Hospital, Colônia Antônio Aleixo, Manaus, Amazonas, Brazil. Source: authors.

DI, total dependence; D2, need for75\% help; D3, need for 50\% help; D4, need for 25\% help; D5, need for supervision; D6, need for minimum help; D7, independence.

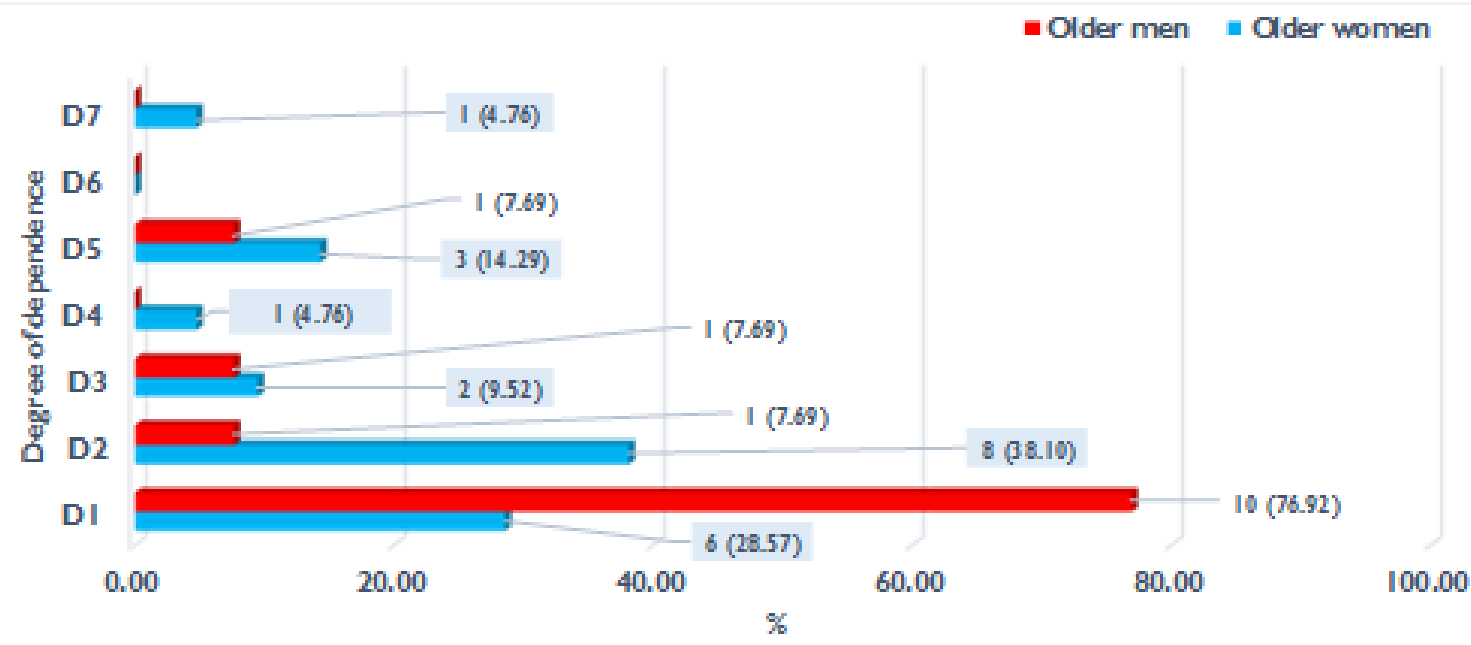

Figure 5 Degree of dependence for the use of public transportation among the older people with leprosy sequelae in the Dr Geraldo da Rocha Hospital, Colônia Antônio Aleixo, Manaus, Amazonas, Brazil. Source: authors.

DI, total dependence; D2, need for75\% help; D3, need for 50\% help; D4, need for 25\% help; D5, need for supervision; D6, need for minimum help; D7, independence. 
According to several studies ${ }^{8,34,44,45}$, older people were totally independent to use public transportation represented approximately $21.40 \%$. As claimed for these researchers, the older people with leprosy sequelae are in a less favourable situation since they had an enormous difficulty to use public transportation due to several factors, among the main reasons reported were: the lack of strength in the superior (arms) and inferior (legs) to get on, hold and balance in the bus.

In this study, it was found that $28.57 \%$ of the older women and $23.07 \%$ of the older men had some difficulty standing (Figure 6). In this item, it was observed only the ability of the older people to get up and stand, without taking into account the ability to remain in this position to walk.

Many of the older people had difficulties in walking, since the vast majority had impairments, for example, by amputation of one of the lower limbs making it impossible for them to stand or remain standing. For this reason, they used trolleys that helped them to move around, but it becomes difficult with these instruments to climb stairs and use public transportation, thus impairing the ability to come and to go for them.

Taking into consideration the ability of these older people to pick up objects on ground/floor, it was found that there were mostly older men with difficulties in relation to older women. Among older men, this difficulty, in general, was present in $76,92 \%$ while among older women this was $57.14 \%$ (Table 7 ). In total, $64.71 \%$ of older men and older women reported difficulties in picking objects on the ground/ floor. It was higher than those found by other researchers, ${ }^{57,58}$ in which about $22.22 \%$ of the older people only reported having difficulties in performing this activity. However, all the above-mentioned situations could be overcome if the institutions to adopt some specific physical and psychological activities that surely will go to improve these conditions. ${ }^{14,58,59-62}$

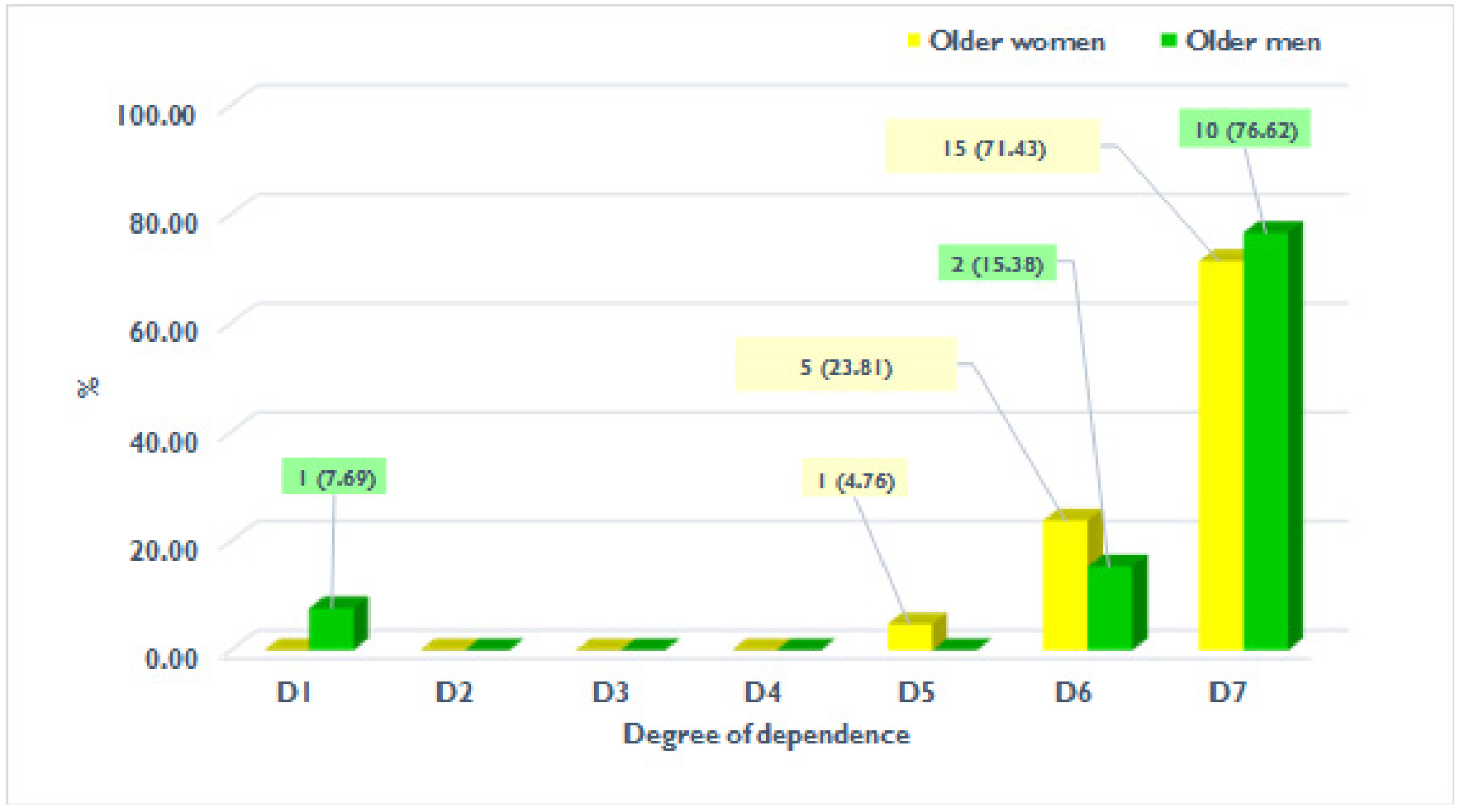

Figure 6 Degree of dependence to stand among the older people with leprosy sequelae in the Dr Geraldo da Rocha Hospital, Colônia Antônio Aleixo, Manaus, Amazonas, Brazil. Source: authors.

DI, total dependence; D2, need for75\% help; D3, need for 50\% help; D4, need for 25\% help; D5, need for supervision; D6, need for minimum help; D7, independence.

Table 7 Degree of dependence to pick up objects on the ground/floor among the older people with leprosy sequelae in the Dr Geraldo da Rocha Hospital, Colônia Antônio Aleixo, Manaus, Amazonas, Brazil.

\begin{tabular}{cllllll}
\hline \multirow{2}{*}{$\begin{array}{c}\text { Variable } \\
\text { To pick up objects on the ground/floor }\end{array}$} & \multicolumn{2}{c}{ Older women } & Older men & \multicolumn{2}{c}{ Total } \\
\cline { 2 - 7 } & $\mathbf{n}$ & $\%$ & $\mathbf{n}$ & $\%$ & $\mathbf{n}$ & $\%$ \\
\hline DI & 0 & 0.00 & $\mathrm{I}$ & 7.69 & $\mathbf{I}$ & $\mathbf{7 . 6 9}$ \\
D2 & 5 & 23.81 & 3 & 23.08 & $\mathbf{8}$ & $\mathbf{2 3 . 5 3}$ \\
D3 & 3 & 14.29 & 2 & 15.38 & $\mathbf{5}$ & $\mathbf{1 4 . 7 1}$ \\
D4 & $\mathrm{I}$ & 4.76 & 0 & 0.00 & $\mathbf{I}$ & $\mathbf{2 . 9 4}$ \\
\hline
\end{tabular}




\begin{tabular}{cllllll} 
Table Continued & \multicolumn{1}{l}{ Variable } & \multicolumn{2}{l}{ Older women } & \multicolumn{2}{l}{ Older men } & \multicolumn{2}{l}{ Total } \\
\cline { 2 - 7 } To pick up objects on the ground/floor & $\mathbf{n}$ & $\%$ & $\mathbf{n}$ & $\%$ & $\mathbf{n}$ & $\%$ \\
\hline D5 & $\mathrm{I}$ & 4.76 & $\mathrm{I}$ & 7.69 & $\mathbf{2}$ & $\mathbf{5 . 8 8}$ \\
D6 & 2 & 9.52 & 3 & 23.08 & $\mathbf{5}$ & $\mathbf{1 4 . 7 1}$ \\
D7 & 9 & 42.86 & 3 & 23.08 & $\mathbf{1 2}$ & $\mathbf{3 5 . 2 9}$ \\
Total & $\mathbf{2 1}$ & 100.00 & $\mathbf{1 3}$ & 100.00 & $\mathbf{3 4}$ & $\mathbf{1 0 0 . 0 0}$
\end{tabular}

Source: authors; $\mathbf{n}$, sample size; \%, percentage

DI, total dependence; D2, need for75\% help; D3, need for 50\% help; D4, need for 25\% help; D5, need for supervision; D6, need for minimum help; D7, independence,

In consonance with the Health Ministry, ${ }^{63,58}$ the functional dependence of older people is almost always associated with loss of autonomy. Once older people demonstrated some degree of dependence to manage their financial resources or to buy food and basic consumer goods, they begin to have their autonomy undermined. As a result, other people will manage their financial assets, they do shop and decide what can or cannot do. The research also showed that about $64.71 \%$ of the older people had full autonomy to manage their finances. However, $32.35 \%$ reported having some kind of difficulty to properly manage their wages, Some of these are: to go to the bank (receive the money), to make mathematical calculations, among others, thus requiring help from the persons who live with them. Only $2.94 \%$ need plenty of help to manage their finances. The results of this study are similar to other researches ${ }^{9,28}$ in other cities of Brazil, in which the index of independent older people to manage their finances was about $55.00 \%$. A slightly higher autonomy was observed among the older people with leprosy sequelae. When asked about the ability to go shopping near their homes, $88.24 \%$ of them reported having some degree of difficulty to realize this activity.
On the other hand, to use the telephone, the percentage of older people who had difficulty came out to $17.65 \%$, with no difference between the sexes (Figure 7). They find it difficult to go shopping due to numerous reasons such as problems to move around, impediments to use the money or inability to carry the purchases. This difficulty can be observed in other studies with the older people conducted by Alves et al. ${ }^{29}$ in which about $79.10 \%$ of the older people interviewed needed that their purchases were made by their caregivers.

It was found that the percentage of older people who presented some degree of dependence to perform light domestic cleaning, such as washing dishes and cleaning the bed was $55.80 \%$. There was an increase in this percentage to $76.47 \%$ when considering the heavy domestic cleaning, some of them were: sweeping the house, washing clothes and carrying weight (Figure 8). The inability to perform activities such as domestic cleaning or washing clothes may compromise the proper cleaning of the house and of the older people themselves. It can also lead to feelings of guilt or low self-esteem due to the inability to perform such activities independently.

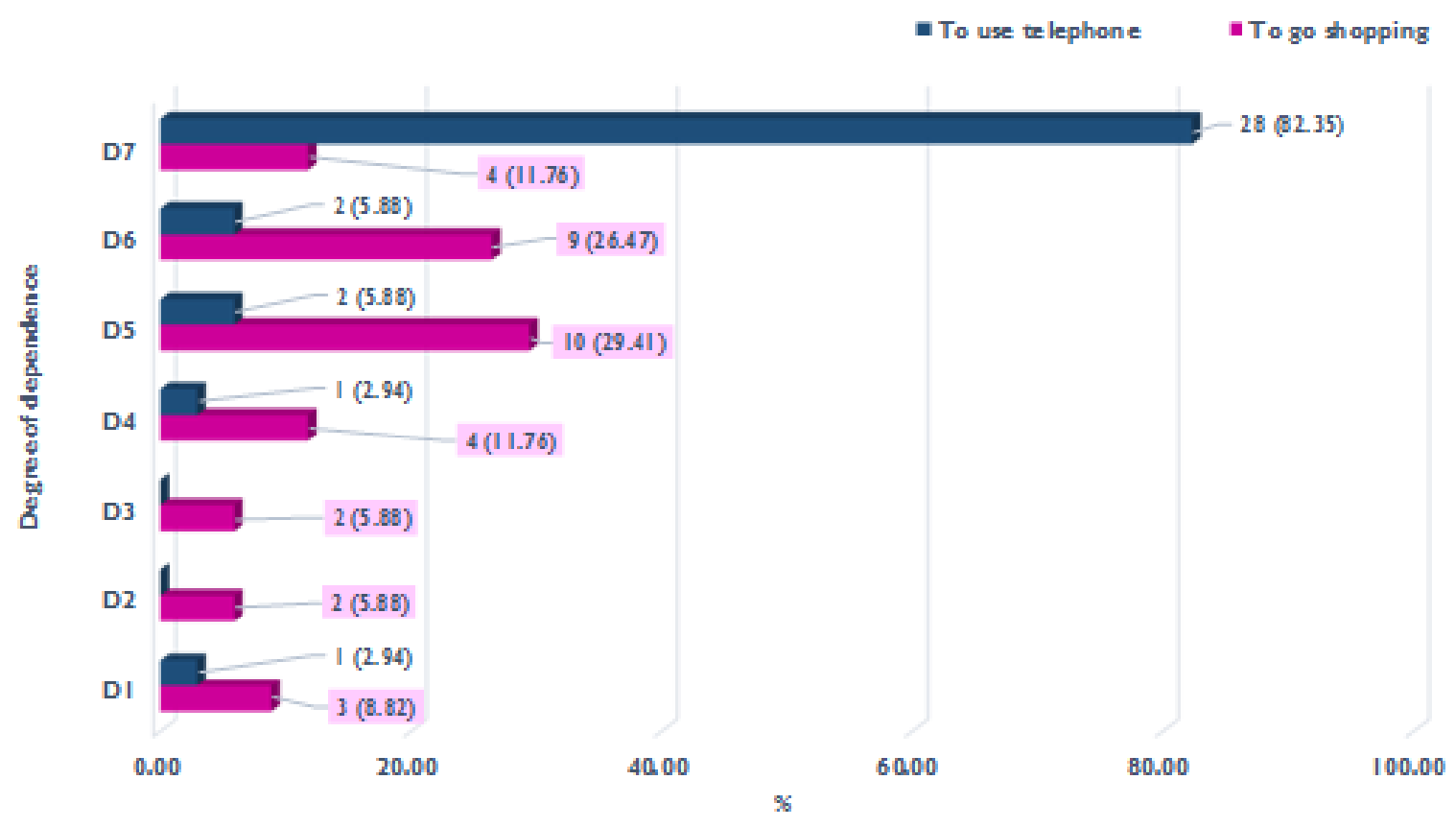

Figure 7 Degree of dependence to use the telephone and to go shopping among the older people with leprosy sequelae in the hospital Dr Geraldo da Rocha, Colônia Antônio Aleixo, Manaus, Amazonas, Brazil. Source: authors.

DI, total dependence; D2, need for75\% help; D3, need for 50\% help; D4, need for 25\% help; D5, need for supervision; D6, need for minimum help; D7, independence. 
In accordance with the data presented above, there is a high level of dependence and need for help in IADLs, which are the most complex activities, such as cleaning the house and shopping. Through these indexes can be constated the existence of gradual loss of functions, going from those deeper involving coordination and reasoning to those of more general actions, such as bathing and dressing. This situation can harm the social life of the older people, since they will need more help from caregivers, having to provide more time, more energy and financial resources to overcome the difficulties installed. ${ }^{8,64-69}$

\section{Closing remark}

Through the application of questionnaires and the observations carried out in the leprosy sector in the Dr Geraldo da Rocha Hospital during this study, we could know some aspects of daily living of older people with leprosy sequelae residents in it, their sociodemographic conditions and also to make an analysis of the functional capacity of these people. In agreement with the results obtained in this study, there was a higher prevalence of leprosy among farmers older women, older men, and the vast majority of them had an income of one minimum wage, married, illiterate, confirming the tendency of older people in Brazil. Although health and quality of life were reported as good, a significant proportion of them considered that they had serious health problems. A large part of older people had a high degree of dependence on Activities of Daily Living (ADLs), especially with climbing stairs, picking up objects from the floor and cutting their toenails. With respect to the Instrumental Activities of Daily Living (IADLs), the greater difficulties were related to public transportation and to going shopping indicating that it is necessary for prevention actions, health promotion and therapeutic interventions by the Health Strategy Teams to delay the continuous decline of the functional capacity of these older people. Leprosy is a serious public health problem in the Northern Region. Thus, this information from the present study can contribute to the planning of actions, to enhance the quality of care, epidemiological surveillance of the mechanism of the disease, and strengthening of the control program in the city of Manaus or elsewhere.

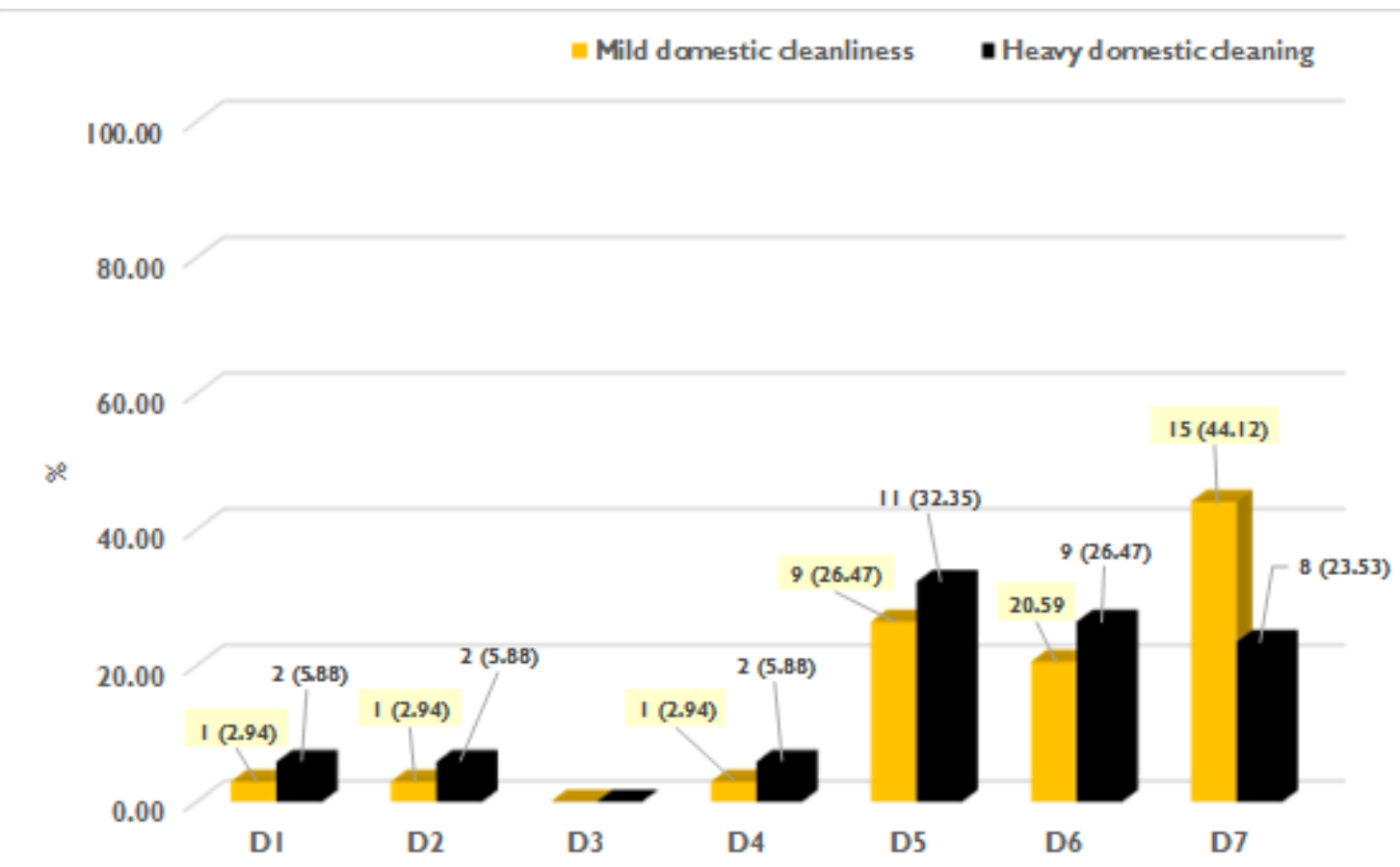

Figure 8 Degree of dependence, to do household cleaning, found among the older people with leprosy sequelae in the Dr Geraldo da Rocha Hospital, Colônia Antônio Aleixo, Manaus, Amazonas, Brazil. Source: authors.

DI, total dependence; D2, need for75\% help; D3, need for 50\% help; D4, need for 25\% help; D5, need for supervision; D6, need for minimum help; D7, independence.

\section{Funding details}

None.

\section{Acknowledgments}

To all older people with leprosy sequelae, nurses and other health agents, caregivers and manager of Dr Geraldo da Rocha Hospital. To Universidade do Estado do Amazonas (UEA) and Fundação de Amparo à Pesquisa do Estado do Amazonas (FAPEAM).

\section{Conflicts of interest}

The authors declare no conflict of interest. 


\section{References}

1. Souza MM de, Silva GB da, Henriques MER de. Significado de ser idoso/Doente de Hanseníase. Rev Eletrônica de Enfermagem. 2005;07(03):327-332

2. Gontijo RW, Leão MR de C. Effectiveness of a preventive physical therapy program for the elderly. Rev Med Minas Gerais. 2013;23(2):173180.

3. Chaimowicz F. The health of elderly Brazilians on the eve of the $21 \mathrm{st}$ century: problems, projections and alternatives. 1996.

4. Junior EPP, Silva IT da, Vilela ABA, et al. Functional dependency and associated factor in elderly living with relatives. Cad Saúde Colet. 2016;24(4):404-412.

5. Brasil. Ministério da Saúde. Secretaria de Políticas de Saúde Departamento de Atenção Básica. Guia para o Controle da hanseníase. Brasília: Ministério da Saúde, 2002. p.:il. - (Série A. Normas e Manuais Técnicos; n. 111). http://bvsms.saude.gov.br/bvs/publicacoes/guia_de_ hanseniase.pdf

6. Brazil. ministry of health. health surveillance secretariat. communicable disease surveillance department. Guidelines for surveillance, care and elimination of Hansen's disease as a public health problem: technical operational manual [electronic resource]/ Ministry of Health, Secretariat of Health Surveillance, department of surveillance of communicable diseases. - Brasília: Ministry of Health, 2016: 58.

7. Eidt LM. Brief history of leprosy: its expansion from the world to the Americas, Brazil and Rio Grande do Sul and its trajectory in Brazilian public health. Saude soc. 2004;13(2):76-88.

8. Santana EMF de, Brito KKG de, Jordana de Almeida Nogueira J de A, et al. Deficiencies and disabilities in leprosy: from the diagnosis to discharge by cure. Rev Eletr Enf. 2018;20:v20a15.

9. Nogueira PSF, Marques MB, Coutinho JFV, et al. Factors associated with the functional capacity of elderly people with leprosy. Rev Bras Enferm. 2017;70(4):711-718.

10. Cordeiro RC, et al. Agreement between observers of a physical therapy assessment protocol in institutionalized elderly women. Rev de Fisioter n. 2002;9:69-77.

11. Guimarães LH de CT, Galdino DCA, Martins FLM, et al. Evaluation of the functional capacity of elderly people undergoing physical therapy treatment. 2004

12. Gordilho A, Sergio J, Silvestre J, et al. Challenges to be faced in the third millennium by the health sector in comprehensive care for the elderly. Human aging, UNATI, Rio de Janeiro: UERJ, 2000.

13. Rosa TE da C, Benício MHD, Latorre M do RD de O, et al. Fatores determinantes da capacidade funcional entre idosos. Rev Saúde Pública. 2003;37(1). 40-48

14. Katz S, Ford AB, Moskowitz RW, et al. Studies of illness in the aged. The index of ADL: a standardized measure of biological and psychosocial function. JAMA. 1963;185:914-919.

15. Lawton MP, Brody EM. Assessment of older people: self-maintaining and instrumental activities of daily living. Gerontologist. 1969;(9):179186.

16. Paula JA. Evaluation of the elderly: functional capacity, independence and its relationship with other health indicators. 2007.

17. Wit, NJ de; Schuurmans MJ. Future care for older people in general practice: paradigm shifts are needed. British Journal of General Practice. 2017;67(664):500-501.

18. Fonseca F, Rizzotto MLF. Construction of an instrument for sociofunctional evaluation in the elderly. Paraná, 2008.
19. Camara F, Gerez G, Miranda ML de J, et al. Capacidade funcional do idoso: formas de avaliação e tendências. São Paulo, 2008.

20. Lima-Costa MF, Firmo, JOA e Uchôa E, et al. The structure of self-rated health among older adults: the Bambuí health and ageing study (BHAS) (A estrutura da autoavaliação da saúde entre idosos: projeto Bambuí). Revista de Saúde Pública Dez. 2004;38(06):1-7.

21. Barbetta PA. Estatística aplicada às ciências sociais. Ed. UFSC, 5a Edição, 2002.

22. Fowler J, Jarvis P, Chevannes M. Practical statistics for nursing and health care. Wiley \& sons, London, 2002:213

23. Rouquayrol MZ. Epidemiologia \& Saúde. 6. Ed. Rio de Janeiro: MEDSI, 2003

24. Katz DL, Elmore JG, Wild DMG, et al. Jekel's epidemiology, biostatistics, preventive medicine and public health. Elsevier Saunder. 4th ed, USA, 2014.

25. Medronho RA. Epidemiologia. Atheneu. 2nd ed. 2008:676.

26. Ramos LR. Fatores determinantes do envelhecimento saudável em idosos residentes em centro urbano. Projeto Epidoso, São Paulo. Caderno de Saúde Pública. 2003:19(3):793-797.

27. Brasil. IBGE. Instituto Brasileiro de Geografia e Estatística. Vamos conhecer o Brasil. 2016, http://7a12.ibge.gov.br/vamos-conhecer-obrasil.

28. Hurtado-Guerrero AF, Lopes EAG, Hurtado-Guerrero JC. Functional capacity and sociodemographic conditions of elderly people in the eliza queiroz maciel living center of mnacapuru, Amazonas, Brazil. Int $J$ of Fam Communi Med. 2019;3(6):253-261

29. Alves MJM, et al. Perfil da capacidade funcional do idoso. Minas Gerais, 2008: http://www.abep.nepo.unicamp.br/encontro2008/docspdf/ ABEP20081534.pdf.

30. Ricci NA; Kubota, MT; Cordeiro RC, et al. Concordância de observações sobre a capacidade funcional de idosos em assistência domiciliar. São Paulo: Universidade de São Paulo, 2005. http://www. scielo.br/pdf/rsp/v39n4 /25540.pdf. Camarano AA, Kanso S, Fernandes D. Envelhecimento populacional, perda da capacidade laborativa e políticas públicas brasileiras entre 1992 e 2011. 2013

31. Camarano AA, Kanso S, Fernandes D. Envelhecimento populacional, perda da capacidade laborativa e políticas públicas brasileiras entre 1992 e 2011. 2013.

32. Ferreira JP; Leeson G; Melhado, VR. Cartografias do envelhecimento em contexto rural: notas sobre raça/etnia, gênero, classe e escolaridade. Trab. educ. saúde, Rio de Janeiro. 2019;17(1):e0017612.

33. Sakamoto CS, Nascimento CA, Maia AG. As famílias pluriativas e não agrícolas no rural brasileiro: condicionantes e diferenciais de renda. Rev Econ Sociol Rural. 2016;54(3):561-582.

34. Nogueira IL. Functional capacity of elderly patients attended in SUS primary healthcare units. UEA, 2007.

35. Brasil. Instituto Brasileiro de Geografia e Estatística. Síntese de indicadores sociais: uma análise das condições de vida da população brasileira, Rio de Janeiro: IBGE, 2017.

36. Soares G. Science proves: Faith helps you live better. Jornal da Ciência, Rio de Janeiro; 2005.

37. Reis LA dos; Menezes TM de O. Religiosity and spirituality in the resilience strategies of the long-lived elderly in daily life. Rev Bras Enferm. 2017;70(4):794-799.

38. Oliveira, RM de, Alves, VP. The quality of life of older people from the influence of religiosity and spirituality: care for the institutionalized 
elderly in Caetité(BA). Revista Kairós Gerontologia. 2014;17(3):305327.

39. Neiva RJ; Grisotti M. Representations of leprosy's stigma in the women of the Jequitinhonha Valley-MG. Physis [Internet]. 2019;29(1):e290109.

40. Abdala GA, Kimura M, Duarte YA de O, et al. Religiosity and quality of life related to the health of the elderly. Rev Saúde Pública. 2015;49:55.

41. Melo NCV de, Teixeira KMD, Barbosa TL. Household arrangements of elderly persons in Brazil: analyses based on the national household survey sample (2009). Rev Bras Geriatr Gerontol. 2016;19(1):139-151.

42. Sousa AAAC de, Oliva MTM de, Camargo CL de. Arranjos familiares com pessoas idosas: fatores contributivos. av.enferm. . 2018; 36(3):292301.

43. Marques JS et al. Atitudes sobre a Velhice: Infância, Adolescência Avós e a Intergeracionalidade. Revista de Psicologia da IMED. 2019;11(2):147-165.

44. Souza CDF, Fernandes TRM, Matos TS, et al. Grau de incapacidade física na população idosa afetada por hanseníase no estado da Bahia, Brasil. Acta Fisiatr. 2017;24(1):27-32.

45. Viana L da S, Aguiar MIF de, Vasconcelos PF de, et al. Physical aspect and the repercussions on the quality of life and autonomy of elderly people affected by leprosy. Nurse glob. 2017;16(46):336-374.

46. Helene LMF; Rocha MT. Identificação de alguns problemas psicossociais em portadores de hanseníase utilizando para análise os recursos de informática. Rev Esc Enf. 1998;32(3):199-207.

47. Matos FS, Jesus CS de, Carneiro JAO, et al. Reduction of functiona capacity of elderly residents in the community: a longitudinal study. Collective health science [Internet]. 2018; 23(10):3393-3401.

48. Araújo, M. A. S. et al. Perfil do idoso atendido por um programa de saúde da família em Aparecida de Goiânia - GO. Revista da Universidade Federal de Goiás, 2003, 5(2)19-23. https://www.revistas. ufg.br/revistaufg/article/view/49770

49. Nunes JD, Saes M de O, Nunes BP, et al. Indicadores de incapacidade funcional e fatores associados em idosos: estudo de base populacional em Bagé, Rio Grande do Sul Epidemiol Serv. 2017;26(2):295-304.

50. Nakatani AYK. Functional capacity in elderly in the community and interventions proposed in the team health. Rev Eletr Enf. 2009;11(1):144-150.

51. Arrais PSD; Fernandes, MEP; Pizzol T da S dal. Prevalence of selfmedication in Brazil and associated factors. Rev Saúde Pública. 2016;50(Supl 2):13s.

52. Garcia AL de F, Madoz KAN, Ferreira EA, et al. Self-medication and adherence to drug treatment: evaluation of participants in the Universidade do Envelhecer program. Rev bras geriatr gerontol. 2018;21(6):691-700.

53. Secoli SR, Marquesini EA, Fabretti S de C, et al. Trend in the practice of self-medication among elderly Brazilians. 2006 e 2010: Estudo SABE. Rev Bras Epidemiol. (Suppl 2): E180007.
54. Rodrigues MCS, Oliveira C. Drug-drug interactions and adverse drug reactions in polypharmacy among older adults: an integrative review. Rev Latino-Am Enfermagem. 2016;24:e2800.

55. Lima M. Perfil da hanseníase no distrito Federal no período de 2000 a 2005. Com. Ciências Saúde. 2008;19(2):163-170.

56. Navarro FM. Convivência familiar e independência para atividades de vida diária entre idosos de um centro dia. Paraná, 2006

57. Letti FB, Laureano L, DIAS SL de A, et al. Evaluation of the degree of functional capacity of institutionalized elderly. Itajaí, 2004.

58. Brazil. Ministry of Health. secretariat of health surveillance. department of epidemiological surveillance. self-care in leprosy: face, hands and feet / ministry of health, department of health surveillance, Department of Epidemiological Surveillance - Brasília: Publisher of the Ministry of Health, 2010: 72

59. Guedes FM; Silveira RCR. Análise da capacidade funcional da população geriátrica institucionalizados na cidade Passo Fundo - RS. In: Revista Brasileira de Ciências do Envelhecimento Humano. Passo Fundo, 10-21 - jul./dez. 2004. http://seer.upf.br/index.php/rbceh/article/ view/10/32.

60. Maciel MG. Physical activity and functionality of the elderly. Motriz Rio Claro. 2010;16(4):1024-1032.

61. Okimura-Kerr T; Okuma SS. Critical attitude of the elderly about physical activity. Rev bras Educ Fís Esporte. 2012;26(4):717-729.

62. Letti FB; Laureano L; DIAS SL de A, et al. Avaliação do grau de capacidade funcional de idosos institucionalizados. Itajaí, 2004. http:// www.inicepg.univap.br/cd/INIC 2004/trabalhos/inic/pdf/IC4-26R.pdf.

63. Brasil. MS. Portaria $\mathrm{n}^{\circ} 2.528$ de 19 de outubro de 2006 http://bvsms. saude.gov.br/bvs/saudelegis/gm/2006/prt2528_19_10_2006.html.

64. Padovani C; Lopes MC de L, Higahashi IH, et al. Being a caregiver for people with Parkinson's Disease: experienced situations. Rev Bras Enferm. 2018;71(Supl 6):2628-2634.

65. Santos KCB dos, TB Cavalcante. MES Lima Leprosy in the elderly: integrative review. Enciclopedia Biosféra. 2019;16(29):2043.

66. Silva DDB da, Tavares CM, Gomes NMC, et al. A hanseníase na população idosa de Alagoas. Rev bras geriatr. gerontol. 2018;21(5):553561

67. Farías-Antúnez S. Incapacidade funcional para atividades básicas e instrumentais da vida diária: um estudo de base populacional com idosos de Pelotas. Epidemiologia e Serviços de Saúde [online]. 2018;27(2):e2017290.

68. Teixeira CSS, Medeiros DS de, Alencar CH, et al. Nutritional aspects of people affected by leprosy, between 2001 and 2014, in municipalities in the Brazilian semiarid region. Ciênc. saúde coletiva. 2019;24(7):24312441 .

69. Lima CA. Functional dependence and risk of falls in the elderly in the home environment and associated factors. $C \& D$-Revista Eletrônica da FAINOR. 2019;12(3):687-704. 